\title{
Thermodynamics and mechanism of complexation of peptides with 18-crown-6 in water
}

\author{
Oleg V. Kulikov and Gennady A. Krestov
}

Institute of Non-Aqueous Solution Chemistry of RAS, 1 Akademicheskaya Str., 153045 Ivanovo, Russia

\begin{abstract}
Taking into account the unusual crystalline structures of 18-crown-6/peptides/water complexes, the links between their thermokinetic behaviour and the structural peculiarities are discussed. It has been found that the peptide chain lengthening leads to an increase in the temperature and activation energy of decomposition. The thermodynamics of complexation between small peptides and 18-crown-6 in water has been studied as well. It is shown that the influence of the peptide lengthening and the presence of a methyl group in the peptide side chain on the binding constant can be used as a the basis for the separation of peptide mixtures in solution.
\end{abstract}

\section{DISCUSSION}

\section{Structure of the crystalline compounds of amino acids and peptides with 18-crown-6}

The study of complex formation between peptides and macrocyclic ligands is important in the understanding of numerous biochemical processes and for the design of new materials possessing unusual properties.

As shown by X-ray diffractometry ${ }^{1}$, the crystalline compounds consisting of zwittterionic peptides and 18crown- 6 are formed by a set of hydrogen bonds. The charged ammonium group of the peptide are bound to the macrocycle oxygen atoms through three $\mathrm{NH}$...O hydrogen bonds resulting in the approximately perpendicular orientation of the peptide backbone to the macrocycle plane (Fig.1). A significant difference in the "depth of penetration" of the ammonium groups into the macrocycle cavity for complexes of 18crown- 6 with diglycine and dialanine was also found. In the 18-crown-6/diglycine complex, the ammonium
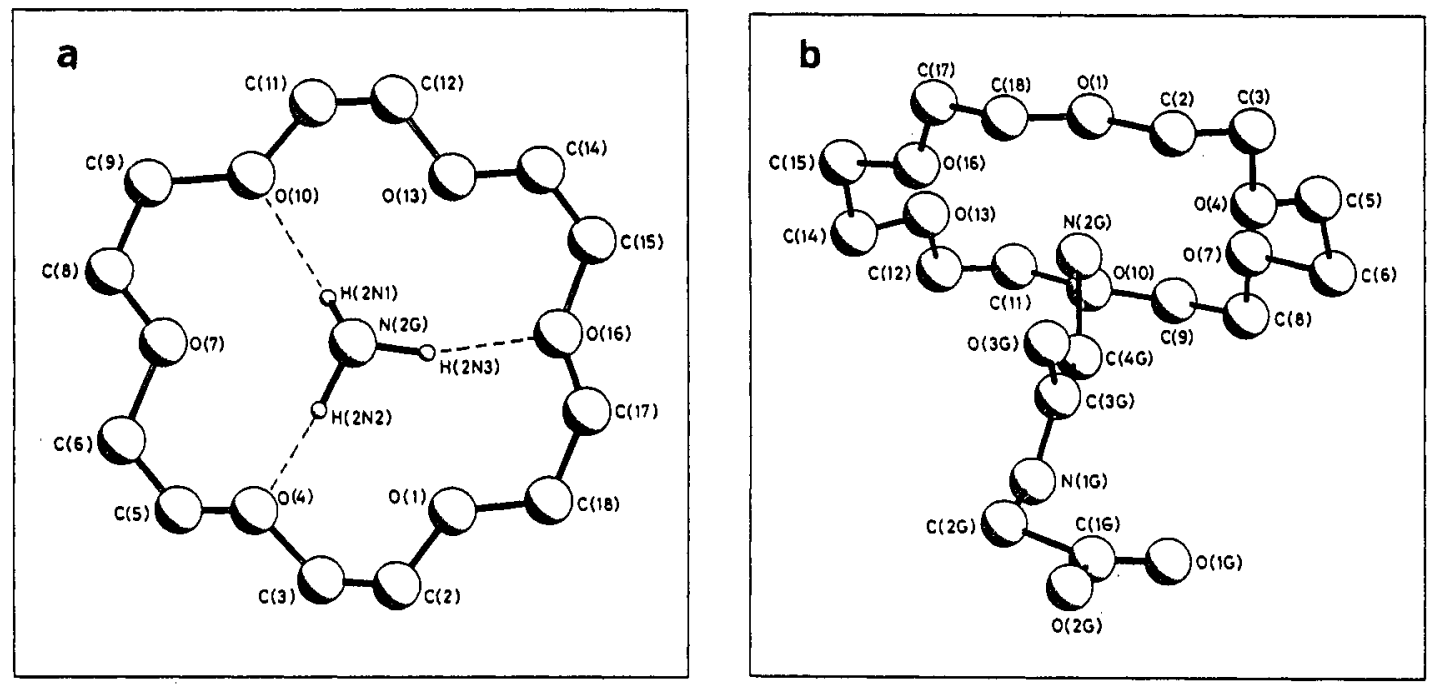

Figure 1. Crystalline structure of the 18-crown/diglycine/water complex. 


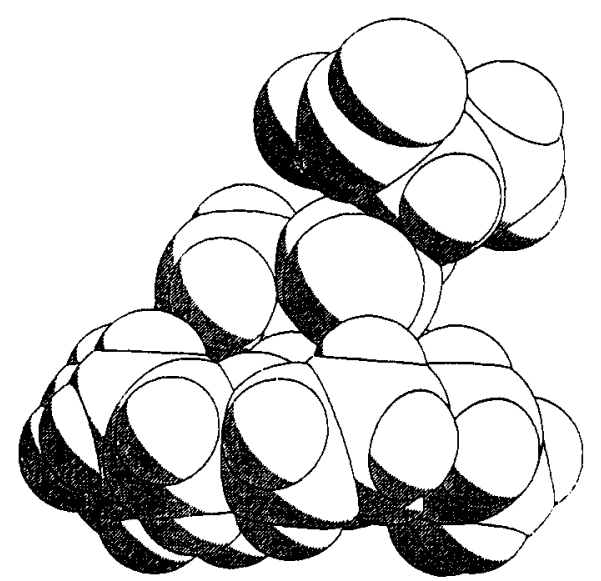

Figure 2. Model of 18-crown-6/dialanine/water complex illustrating the steric hindrance of a methyl group.

cation is closer to the ring. This result can be explained by steric hindrance associated with the presence in 18-crown-6/dialanine of the methyl side group in proximity to the ammonium group (Fig.2 illustrates the steric hindrance appearing in the dialanine complex). The carboxylic group at the opposite side of the peptide molecule takes part in hydrogen bonding with water molecules.

The molecular packing of the different dipeptide complexes has one common feature. There are separate areas of lower polarity formed by double layers of crown ethers and other areas of higher polarity formed by the peptides and water (Fig.3). The higher content of water in the crystalline complexes allows formation of a three-dimensional network of hydrogen bonds. Such original, laminated structures of the crystals are similar to the molecular conductors and Langmuir-Blodgett films.

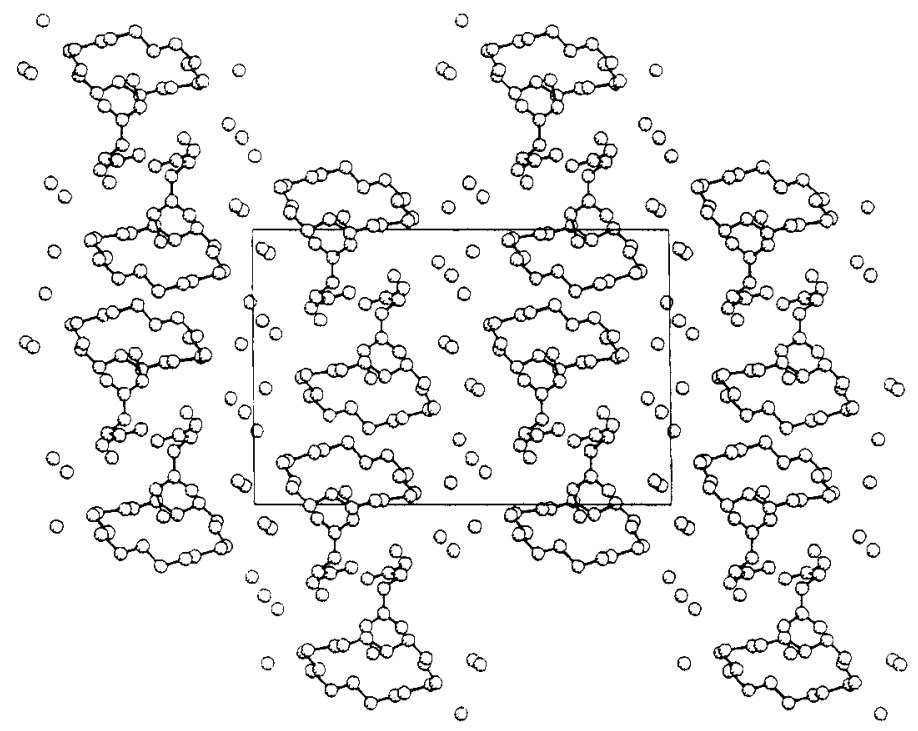

Figure 3. Molecular packing in 18-crown-6/diglycine/water

\section{Stability and decomposition mechanism of the hydrated complexes.}

Taking into consideration the peculiarities outlined, it was important to study thermal stability and thermokinetic behavior of hydrated compounds consisting of 18-crown- 6 and peptides of different length and structure by differential scanning calorimetry (DSC) and thermogravimetry (TG) methods 2,3 . On the DSC and TG thermograms (Fig.4), several endothermic peaks corresponding to different stages of the decomposition of complexes are found. There is dehydration at $25-75^{\circ} \mathrm{C}$, mutual dehydration-dissociation of the complexes at $75-125^{\circ} \mathrm{C}$ and separate ligand dissociation processes (second or third peaks). 

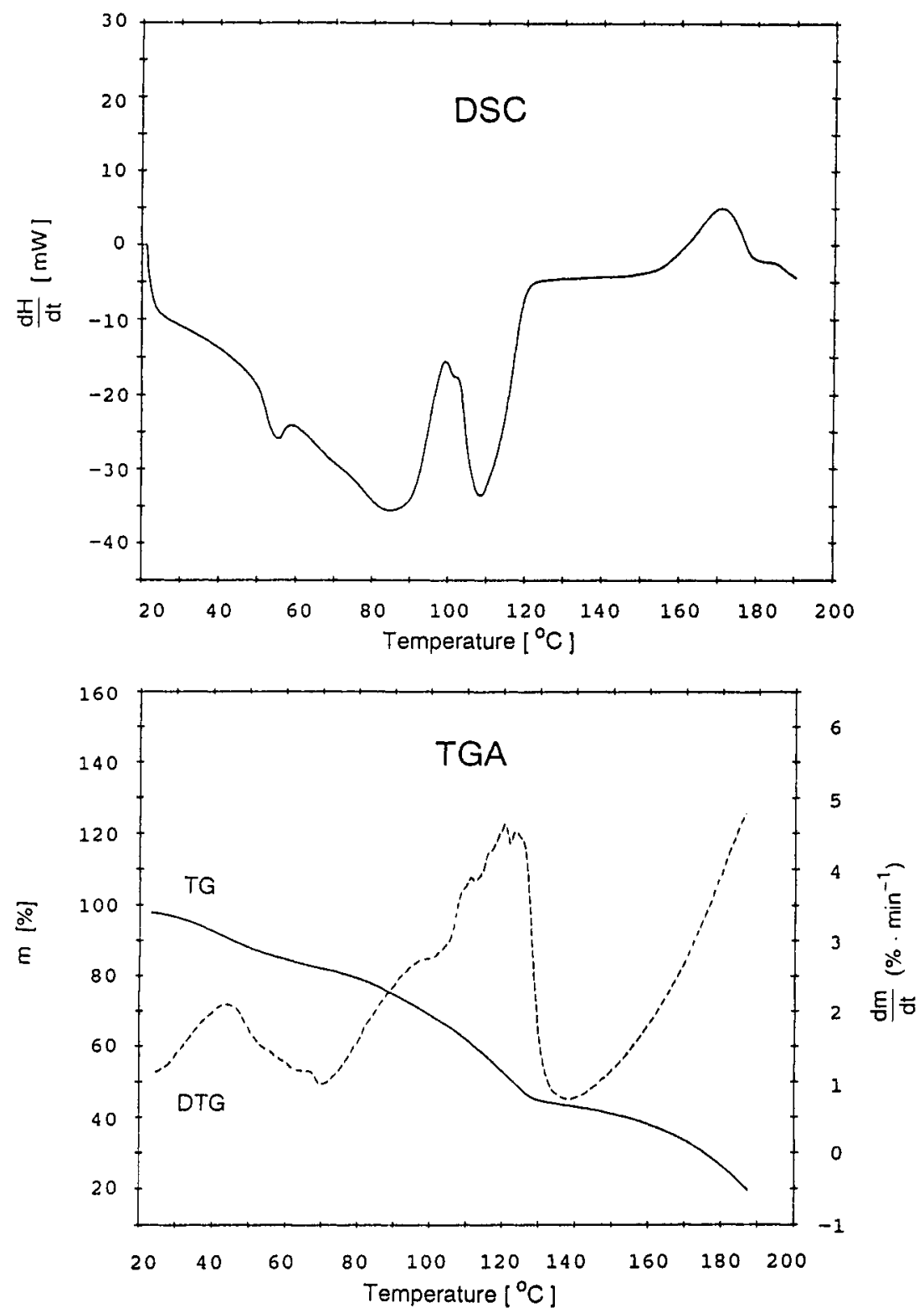

Figure 4. DSC and TG thermograms of the 18-crown-6/diglycine/ $\mathrm{nH}_{2} \mathrm{O}$ complexes

The possible mechanisms of thermal reactions of the 18-crown-6/peptide/water complexes can be represented in the following ways

(A) 18-crown-6/peptide $\left./ \mathrm{nH}_{2} \mathrm{O}\right) \rightarrow$ 18-crown-6 + peptide $+\mathrm{nH}_{2} \mathrm{O}(\mathrm{g})$

(B) 18-crown-6/peptide/ $\left.\mathrm{nH}_{2} \mathrm{O}\right) \rightarrow$ 18-crown-6/peptide/(n-i) $\mathrm{H}_{2} \mathrm{O}(\mathrm{g})+\mathrm{iH}_{2} \mathrm{O}(\mathrm{g})$

$$
\rightarrow \text { 18-crown-6 + peptide }+(\mathrm{n}-\mathrm{i}) \mathrm{H}_{2} \mathrm{O}(\mathrm{g})
$$

Thermal decomposition (A) proceeds in one stage with simultaneous dehydration and thermal dissociation of the complex. It is characteristic for complexes consisting of $\alpha$-amino acids and alanyl-containing peptides. The complexes with glycyl-containing dipeptides follow the three stage decomposition according to the mechanism (B). 
Besides the difference in the decomposition mechanism of complexes with glycyl and alanyl-containing peptides, the glycyl-containing complexes have the higher temperature and activation energy of decomposition (Table 1). Consequently the closer approach of the glyclyl group to the macrocycle plane determines the greater stability of these complexes in comparison with that of complexes bound to 18crown-6 through an alanyl group.

TABLE 1. Enthalpic and kinetic parameters of decomposition of 18-crown-6/peptide complexes.

\begin{tabular}{lcccc}
\hline Compound & $\mathrm{M}_{\mathrm{c}}^{\mathrm{a}}$ & $\begin{array}{c}\mathrm{T}^{\mathrm{b}} \\
\mathrm{K}\end{array}$ & $\begin{array}{c}\Delta \mathrm{H}^{\mathrm{c}} \\
\mathrm{kJ} \cdot \mathrm{mol}^{-1}\end{array}$ & $\begin{array}{c}\mathrm{E}_{\mathrm{a}} \\
\mathrm{kJ} \cdot \mathrm{mol}^{-}\end{array}$ \\
\hline 18-crown-6/glycine/2 $\mathrm{H}_{2} \mathrm{O}$ & 375.4 & 343.1 & 129 & $69(2)$ \\
18-crown-6/diglycine/ $\mathrm{H}_{2} \mathrm{O}$ & 414.5 & 364.9 & 107 & $106(4)$ \\
18-crown-6/diglycine $2 \mathrm{H}_{2} \mathrm{O}$ & 432.5 & 377.7 & 139 & - \\
18-crown-6/triglycine/ $/ \mathrm{H}_{2} \mathrm{O}$ & 471.5 & 372.5 & 24 & $126(6)$ \\
18-crown-6/triglycine & 453.5 & 414.4 & 28 & - \\
18-crown-6/L-a-alanine/2 $2 \mathrm{H}_{2} \mathrm{O}$ & 389.4 & 333.8 & 111 & $53(1)$ \\
18-crown-6/dialanine/ $2 \mathrm{H}_{2} \mathrm{O}$ & 460.5 & 361.2 & 133 & $100(3)$ \\
18-crwon-6/trialanine $/ 2 \mathrm{H}_{2} \mathrm{O}$ & 531.6 & 371.1 & 117 & $109(3)$ \\
\hline
\end{tabular}

aMolecular mass of complexes. ${ }^{b}$ The temperatures of the peaks are presented. ${ }^{c}$ All values were calculated with molecular mass presented in the first column.

Another important phenomena is the increase of the decomposition temperature with the rise of peptide chain length; this is reflected in Fig.5. In the case of dipeptide complexes, hydrogen bonds are formed also between the amide groups of antiparallel arranged peptide backbones of the neighboring complexes. This stabilizes additionally the crystalline structures in comparison with $\alpha$-amino acids complexes, which are not able to from direct hydrogen bonds between complexes. Therefore the temperatures and activation energies of decomposition of the complexes with amino acids are lower. The additional bonding between two pairs of amide groups in triglycine/18-crown-6 leads to the linear increase of decomposition temperature (Figure 5). This dependence is not linear for alanyl-containing complexes. Thus, the structure peculiarities of the complexes of $\alpha$-amino acids and peptides with 18-crown- 6 in the crystalline state are significantly reflected in their thermokinetic characteristics. Molecular materials with unusual properties are thus obtained.

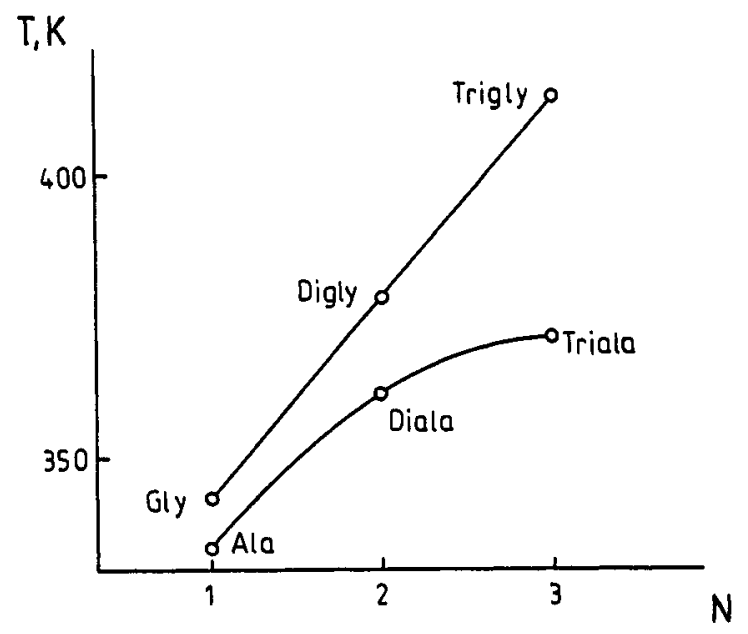

Figure 5. Temperatures of decomposition of glycyl and alanyl containing complexes versus the number of amino acid residues. 


\section{Thermodynamics of complexation of $\alpha$-amino acids and peptides with 18-crown-6 in water.}

Results of A. F. Danil de Namor and co-authors $4,5,6$ on the thermodynamics of complexation of amino acids with 18-crown-6 in alcohols have appeared recently. Here we present the stability constants, enthalpies and entropies of complexion of glycine, L- $\alpha$-alanine and some peptides with 18-crown- 6 in water. These data are collected in Table 2.

The aqueous medium corresponds to the natural surroundings where biochemical reactions take place. Therefore, to show the role of hydration is very important task. The amino acids and peptides investigated have been chosen in order to study the influence of a peptide lengthening and the presence of methyl group in the peptide side chain on the complexation with crown ether.

Differing from the alcoholic media ${ }^{6}$, the stability constants for binding of amino acids in water are significantly lower (Table 2); this is caused by their stronger solvation in water. Our data show that much lower stability constants and enthalpies of binding are observed for $L-\alpha$-alanine in comparison to glycine.

TABLE 2. Stability constants, free energies, enthalpies and entropies of binding of amino acids and peptides with 18 -crown- 6 in water at $298.15 \mathrm{~K}$.

\begin{tabular}{lcccc}
\hline \multicolumn{1}{c}{ Solutes } & $\begin{array}{c}\mathrm{K}_{\mathrm{B}} \\
\left(\mathrm{mol} \mathrm{kg}^{-1}\right)\end{array}$ & $\begin{array}{c}\Delta \mathrm{G}_{\mathrm{B}} \\
\mathrm{kJ} \mathrm{mol}^{-}\end{array}$ & $\begin{array}{c}\Delta \mathrm{H}_{\mathrm{B}} \\
\mathrm{kJ} \mathrm{mol}^{-1}\end{array}$ & $\begin{array}{c}\Delta \mathrm{S}_{\mathrm{B}} \\
\mathrm{J} \mathrm{mol}^{-1}\end{array}$ \\
\hline Glycine+18-Crown-6 & $4.45 \pm 0.1$ & -3.70 & $-10.46 \pm 0.0$ & -22.7 \\
Diglycine+18-Crown-6 & $5.05 \pm 0.2$ & -4.01 & $-8.75 \pm 0.0$ & -15.9 \\
Triglycine+18-Crown-6 & $5.73 \pm 0.0$ & -4.33 & $-8.30 \pm 0.0$ & -13.3 \\
L- $\alpha$-Alanine+18-Crown-6 & $2.51 \pm 0.0$ & -2.28 & $-8.17 \pm 0.0$ & -19.8 \\
L- $\alpha$-Alanyl-L- $\alpha$-alanine+18-Crown-6 & 5.73 & -4.32 & $-3.33 \pm 0.0$ & 3.3 \\
DL- $\alpha$-Alanylglycyl-glycine+18-Crown & 8.05 & -5.17 & $-1.63 \pm 0.0$ & 11.9 \\
\hline
\end{tabular}

The lengthening of the peptide backbone from glycine to triglycine leads to a small increase of the binding constants and to a decrease of the negative enthalpic and entropic terms. Therefore, the lengthening of a peptide molecule makes the peptide-crown interaction less enthalpically favorable in accordance with their rise of the exothermic enthalpy of peptide hydration and to the strengthening of their hydration 7,8,9. Fig. 6 illustrates the competition effect between complexation and the hydration of host and guest on the enthalpy

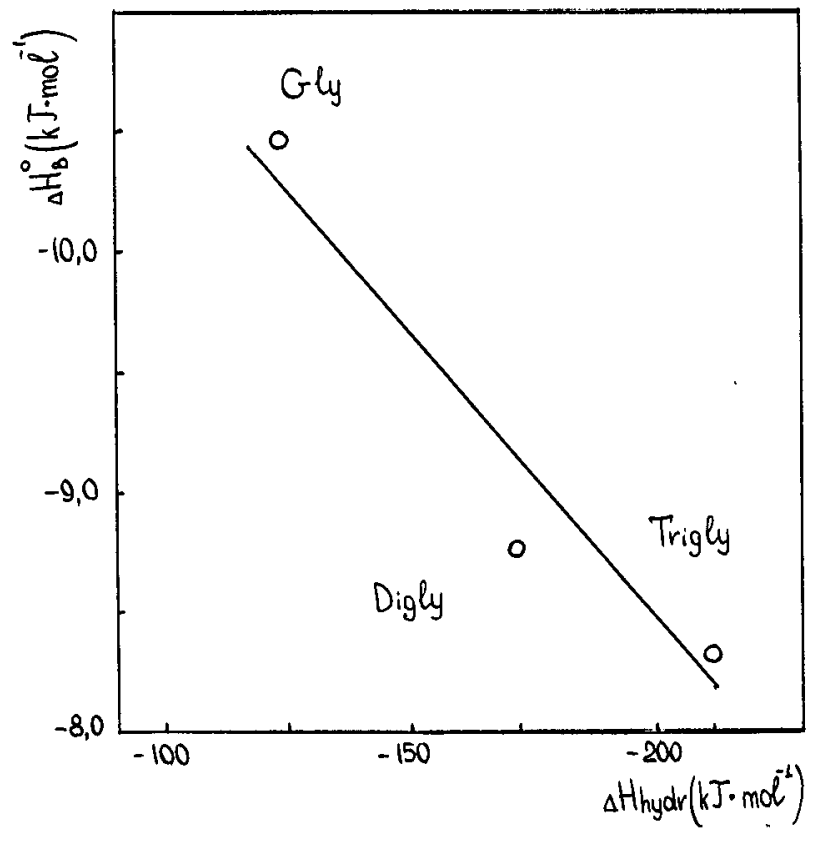

(C) 1995 IUPAC, Pure and Applied Chemistry, 67, 1103-1108
Figure 6. Enthalpies of binding of glycylcontaining peptides to 18 -crown- 6 in water at $298.15 \mathrm{~K}$ versus the enthalpies of hydration of the peptides. 
of binding. However, the bigger change of the entropy results in an increase of the free energy of binding with the lengthening of peptides. Thus, the increase of the stability constants with the lengthening of the peptides is controlled by the entropic term.

The difference in the stability constants for the complexation of diglycine and dialanine with 18-crown-6 is not so significant as for complexation of amino acids forming these peptides. The introduction of a methyl group makes the complexation more entropically favorable and less enthalpically favorable. Due to this, the constant of binding of dialanine with 18-crown-6 is bigger by the factor of two compared with that for L- $\alpha$-alanine (Table 2). Thus, the presence of the methyl groups in the di- and tri- peptides in close proximity to the ammonium $\mathrm{NH}_{3}{ }^{+}$end group does not only prevent the complexation, but, on the contrary, promotes that in accordance with the weakening of the specific hydration of the peptides. This becomes quite evident for the triglycine and DL-a-alanylglycylglycine complexation (Table 2), where in latter case the binding constant increases.

Considering the influence of the factors studied, it can be concluded that the increase of length of the peptide molecule promotes the complexation with 18 -crown- 6 , in spite of the simultaneous strengthening of the specific hydration of the peptides. Such dependence of binding constants for peptide-crown complexation can be used as a basis for the separation of peptides of different length in solution.

Acknowledgment. This work was partially supported by a grant from The International Science Foundation (USA).

\section{REFERENCES}

1. J. Lipkowski, O. V. Kulikov, and W. Zielenkiewicz, J. Supramolec. Chem., 1, 73 (1992)

2. O. V. Kulikov,W. Zielenkiewicz, E. Utzig and G. A. Krestov, Thermochim. Acta, 213, 103 (1993)

3. O. V. Kulikov, W. Zielenkiewicz and E. Utzig, Thermochim. Acta, 237, 333 (1994)

4. A. F. Danil de Namor, Pure Appl. Chem., 62, 2121 (1990)

5. A. F. Danil de Namor, M. C. Ritt, D. F. Lewis, M. J. Schwing-Weil and F. A. Neu, Pure Appl.

Chem., 63, 1435 (1991)

6. A. F. Danil de Namor, M. C. Ritt, M. J. Schwing-Weil, F. A. Neu, and D. F. Lewis, J. Chem. Soc. Faraday Trans., 87, 3231 (1991)

7. M. Aby-Hamdlyyah and A. Shehabuddin, J. Chem. Eng. Data, 27, 74 (1982)

8. G. C. Kreshek and L. Benjamin, J. Phys. Chem., 68, 2467 (1964)

9. C. G. de Kruif, J. Voogd, and J. C. Offringa, J. Chem. Thermodyn., 11, 651 (1979) 